\title{
A selective de- $O$-methylation of guaiacyl lignans to corresponding catechol derivatives by 2-iodoxybenzoic acid (IBX). The role of the catechol moiety on the toxicity of lignans
}

\author{
Roberta Bernini, ${ }^{* a}$ Maurizio Barontini, ${ }^{a}$ Pasquale Mosesso, ${ }^{a}$ Gaetano Pepe, ${ }^{a}$ Stefan M. Willför, ${ }^{b}$ \\ Rainer E. Sjöholm, ${ }^{b}$ Patrik C. Eklund $^{b}$ and Raffaele Saladino*a $^{* a}$
}

Received 17th December 2008, Accepted 5th March 2009

First published as an Advance Article on the web 3rd April 2009

DOI: 10.1039/b822661j

We report here the first selective de- $O$-methylation of a large panel of guaiacyl lignans to the corresponding catechol derivatives by using IBX as primary oxidant under green conditions (dimethyl carbonate- $\mathrm{H}_{2} \mathrm{O}$ solvent) through an in situ reduction procedure. The influence of the catechol moiety on the cytotoxicity and genotoxicity of new lignan derivatives has been investigated. The results obtained indicated that the presence of the catechol moiety sharply enhances the clastogenic potential (e.g. induction of chromosomal aberrations), the cytotoxicity and the modulation of cell cycle progression with respect to the parent compounds. Thus, despite the in vitro antioxidant activity usually described for catechol derivatives, our results show for the first time the generation of a clastogenic potential, highly indicative of a long-term genetic and cancer risk.

\section{Introduction}

Lignans are a large family of natural phenols, widely diffused on the plant kingdom, and characterized by the $\beta-\beta^{\prime}$-linkage between two phenylpropane units or between their biogenetic equivalents. ${ }^{1}$ These compounds, having different degrees of oxidation of the side chain or differences in the aromatic substitution, show several biological activities, ${ }^{2}$ including antiviral, ${ }^{3}$ antitumoral, ${ }^{4}$ antiinflammatory ${ }^{5}$ and antioxidant properties. ${ }^{6}$

Once introduced into an organism, lignans are metabolized by the action of oxidative enzymes containing the cytochrome P-450 molecule as a cofactor at the reactive site. ${ }^{7}$ During these metabolic pathways, lignans can be de- $O$-methylated at the guaiacyl or syringyl groups in the aromatic moieties, oxidized at reactive benzylic positions by oxygen atom insertion into the $\mathrm{C}-\mathrm{H}$ bond, or transformed to corresponding hydroquinones, catechols and ortho- or para-benzoquinone derivatives. It is worth noting that highly oxidized forms of phenol derivatives, such as quinones and hydroquinones, can modify the value of the redox-potential in the cell. This process, which has consequences for the lifetime of the cell, is performed by various reaction processes. In the first case, highly oxidized phenols react with the components of the cellular machinery devoted to the control of the redox-potential, such as glutathione $(\mathrm{GH})$ and mercapto-group containing proteins (protein-SH). ${ }^{8}$ According to their mode of action, they result in depletion of the molecular redox controllers, mainly by alkylation of the nucleophilic mercapto (SH) group. ${ }^{9}$ Alternatively, highly oxidized phenols can generate reactive oxygen species (ROSs), such as hydroxyl radicals (HO') or peroxyl radicals (HOO'), with a

${ }^{a}$ Department of Agrobiology and Agrochemistry, University of Tuscia, 01100 , Viterbo, Italy.E-mail: berninir@unitus.it, saladino@unitus.it; Fax: +39 0761 357242; Tel: +390761 357452-357284

${ }^{b}$ Åbo Akademi Process Chemistry Centre, Åbo Akademi University, Porthansgatan 3, FI-20500, Ảbo, Finland concomitant decrease of $\mathrm{GH}$ and protein-SH, which are sacrificed to protect nucleic acids from radical damage. ${ }^{10}$

More generally, the biological effect of highly oxidized phenols is further complicated by considering their specific electronic properties. In fact, quinones are highly electrophilic species that can easily react with the nucleophilic sites of biomolecules, the reaction proceeding by a Michael-like addition at the $\alpha, \beta$-unsaturated carbonyl moiety present in their structure. This property potentially confers to quinones high genotoxicity and cytotoxicity. On the other hand, hydroquinone and catechol derivatives - the reduced form of quinones - protect nucleic acids by radical damage, entrapping the ROS via a H-abstraction process with generation of less reactive radicals usually stabilized through mesomeric effects. ${ }^{11}$ The oxidation of the reactive benzylic positions in the side-chain can also affect the biological activity.

On the basis of this scenario, it is expected that highly oxidized lignan derivatives should possess biological activities different from that of the parent lignans. Thus, in a systematic approach, the biological activity of lignans should be compared to that of the corresponding oxidized derivatives, to account for their potential metabolic role. Unfortunately, little data is available about the biological activity of oxidized lignans. ${ }^{12}$ This is mainly due to the low quantities of lignan metabolites recoverable from physiological fluids during in vivo treatments (less than ppm of lignan metabolites are detectable by GC-MS and LC-MS analyses of organic samples), associated with the difficulty of designing efficient chemical strategies for the selective oxidation of lignans.

In recent years, we have been involved in the design and development of novel stoichiometric and catalytic procedures for the oxidation of natural phenols, including lignin and lignan derivatives. ${ }^{13}$ For example, the oxidation of podophyllotoxin (a lignan of the aryltetralin family isolated from various plants of the genus Podophyllum) with methyltrioxorhenium $\left(\mathrm{MeReO}_{3}\right.$, MTO), in combination with $\mathrm{H}_{2} \mathrm{O}_{2}$ as primary oxidant, afforded various quinone and isopodophyllotoxone derivatives, some of 
which were not previously reported. ${ }^{14}$ These compounds showed various mechanisms of action, from the inhibition of cell division at the level of the microtubule assembly by freezing polymerization of tubulin (a characteristic of the parent podophyllotoxin), to the inhibition of topoisomerase II, which is a more interesting therapeutic target.

More exciting was that the biological activity is correlated to the oxidation state of the molecule, from (a) the relatively low inhibitory activity towards tubulin polymerization of in $2^{\prime}, 3^{\prime}$-ortho-benzoquinone derivatives, to (b) an enhanced inhibitory activity towards tubulin polymerization and concurrent emergence of antitopoisomerase II activity by oxidation of the C-7 position of the C-ring in isopodophyllotoxone, to (c) a selective activity against topoisomerase II when the oxidation of the C-7 position was accompanied by the ring-opening of the D-lactone moiety. A similar structure-activity relationship was observed in the apoptogenic activity of products of oxidation of galbulin, another aryltetraline lignan isolated from Galbulimima belgraveana, against both human lymphoma cell line BL41 (EBV-), prone to apoptosis, and $\mathrm{E} 2 \mathrm{R}(\mathrm{EBV}+)$, which is strongly resistant to chemical treatment. ${ }^{14}$

As a continuation of this study, with the aim to further elucidate the biological activity of highly oxidized lignan derivatives, we focused our attention on the de- $O$-methylation of the guaiacyl (4-hydroxy-3-methoxyphenyl) moiety to the corresponding catechol (3,4-dihydroxyphenyl) group. In fact, despite the higher radical scavenging capacity reported for lignans with catechol (3,4-dihydroxyphenyl) moieties compared to guaiacyl (3-methoxy4-hydroxyphenyl) lignans, ${ }^{6 a}$ no general chemical procedures are available to mimic the metabolic activity of cytochrome P-450 enzymes in the de- $O$-methylation of guaiacyl lignans. ${ }^{15}$ Moreover, even though some cytotoxicity data are available for guaiacyl lignans (mainly matairesinol derivatives), ${ }^{16}$ no cytotoxicity or genotoxicity data are available for de- $O$-methylated guaiacyl derivatives.

An efficient reagent useful for obtaining the catechol moiety from guaiacyl derivatives is 1-hydroxy-1-oxo- $1 H-1 \lambda^{5}$ benz $[d][1,2]$ iodoxol-3-one (2-iodoxybenzoic acid, IBX), first prepared by Hartmann and Mayer by oxidizing 2-iodobenzoic acid (IBA) with potassium bromate in aqueous solution. ${ }^{17} \mathrm{~A}$ convenient and safe procedure for its preparation, involving Oxone as oxidant, was reported by Santagostino and coworkers. ${ }^{18}$ When phenolic methyl ethers are oxidized by IBX, the corresponding ortho-quinone derivatives are obtained. ${ }^{19}$ If this oxidative step is followed by in situ reduction, the catechol moiety is produced, with a selectivity similar to that of a demethylating enzyme. Despite this remarkable capacity, only some examples of catecholic compounds have been prepared using this demethylating-IBX methodology. ${ }^{20}$ Recently, we have been involved in the optimization of this method and its application to a wide variety of natural organic compounds to obtain the corresponding bioactive catechol derivatives. For example, 2-(4-hydroxy-3-methoxyphenyl)ethanol (homovanillyl alcohol), a natural guaiacyl derivative, has been utilized as starting material for the synthesis of 2-(3',4'-dihydroxyphenyl)ethanol (hydroxytyrosol) and its lipophilic derivatives, useful molecules for cosmetic and pharmaceutical applications. ${ }^{21}$ Two patents regarding these results have been deposited. ${ }^{22}$

We report here the first selective de- $O$-methylation of a large panel of representative guaiacyl monolignols and guaiacyl lig- nans and neolignans to the corresponding catechol derivatives by using IBX as the primary oxidant under green conditions (dimethyl carbonate- $\mathrm{H}_{2} \mathrm{O}$ solvent) through the in situ reduction procedure. ${ }^{21,22}$ The role of the catechol moiety on the cytotoxicity and genotoxicity of new lignan derivatives has been investigated.

\section{Results and discussion}

Initially, we studied the de- $O$-methylation procedure with IBX for three representative guaiacyl derivatives, two monolignols (vanillic acid $\mathbf{1}$ and ferulic acid 2) and two dimeric derivatives, (E)-4-(4-hydroxy-3-methoxyphenyl)-2-(4-hydroxy-3methoxyphenylmethyl)but-3-enoic acid 3, which is formed in the treatment of the natural lignan hydroxymatairesinol in strongly basic conditions, ${ }^{23}$ and 5,5'-dihydroxy-4,4'-dimethoxybiphenyl2,2'-dicarbaldehyde 4 (Fig. 1). Since a free carboxylic moiety decreases the efficiency of product extraction in the IBX procedure, acids 1-3 were converted also into the corresponding methyl esters $5-7$ by reported protocols before the oxidative treatment (Scheme 1). ${ }^{23-26}$<smiles>COc1cc(C(=O)O)ccc1O</smiles>

1<smiles>COc1cc(/C=C/C(Cc2ccc(O)c(OC)c2)C(=O)O)ccc1O</smiles>

3

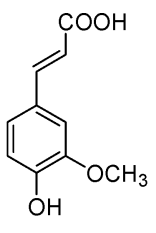

2

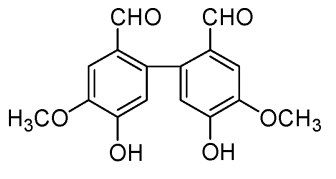

4
Fig. 1 Chemical structure of monolignols 1 and $\mathbf{2}$, and dimeric derivatives 3 and 4.

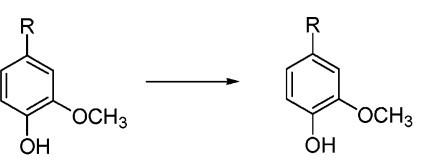

1: $\mathrm{R}=\mathrm{CO}_{2} \mathrm{H}$ 2: $\mathrm{R}=\mathrm{CO}_{2} \mathrm{H}$

5: $\mathrm{R}=\mathrm{CO}_{2} \mathrm{Me}$<smiles></smiles><smiles>COc1cc(/C=C/C(Cc2ccc(O)c(OC)c2)C(=O)O)ccc1O</smiles>

Scheme 1 Methylation of carboxylic acids 1, 2 and 3 with methanol/ sulfuric acid.

As a general procedure, the acids 1-3, methyl esters 5-7, and vanillin derivative $4(1.0 \mathrm{mmol})$ were treated with a small excess of IBX (1.2 equivalents) in $\mathrm{H}_{2} \mathrm{O} / \mathrm{DMC}(1.0: 9.0)$ solution at room temperature for 3-5 hrs. The quenching of the reaction was performed by adding water $(1.0 \mathrm{ml})$ and sodium dithionite $\left(\mathrm{Na}_{2} \mathrm{~S}_{2} \mathrm{O}_{4}, 2.4\right.$ equivalents) over several minutes, with a colour change in the solution being observed. Under these experimental 
Table 1 Oxidation of lignans and neolignans with IBX

\begin{tabular}{llccl}
\hline Entry & Substrate & Product & Conv. $(\%)$ & ${\text { Yield }(\%)^{a}}^{a}$ \\
\hline 1 & $\mathbf{5}$ & $\mathbf{8}$ & $>98$ & 73 \\
2 & $\mathbf{6}$ & $\mathbf{9}$ & 60 & 82 \\
3 & $\mathbf{7}$ & $\mathbf{1 0}$ & $>98$ & $25^{b}$ \\
4 & $\mathbf{1 1}$ & $\mathbf{1 4}$ & $>98$ & 55 \\
5 & $\mathbf{1 2}$ & $\mathbf{1 5}$ & $>98$ & 70 \\
6 & $\mathbf{1 3}$ & $\mathbf{1 6}$ & $>98$ & 40 \\
7 & $\mathbf{1 9}$ & $\mathbf{2 1}$ & 50 & 85 \\
8 & $\mathbf{2 0}$ & $\mathbf{2 2}$ & 65 & $70^{b}$
\end{tabular}

${ }^{a}$ Yield based on conversion of substrate. ${ }^{b}$ Total yield after acetylation.

conditions, the oxidations of acids 1-3 and vanillin derivative 4 failed. In these cases, the low efficiency of the oxidation is in accordance with previously reported data for the reactivity of phenols containing electron-withdrawing groups (EWGs, e.g. $\mathrm{C}(\mathrm{O}) \mathrm{R}$ and $\mathrm{NO}_{2}$ groups) with IBX..$^{19,20}$ On the other hand, the methyl esters of catechol monolignol derivatives such as methyl 3,4-dihydroxybenzoate 8 (methyl protocatechuate) and methyl 3,4-dihydroxycinnamate 9 (methyl caffeate) were obtained in acceptable to high yield (Scheme 2, Table 1, entries 1 and 2). To the best of our knowledge, the de- $O$-methylation of vanillic acid and ferulic acid has only previously been reported using enzymatic systems. ${ }^{26}$ In the case of 7 we were able to isolate the reaction product, methyl (3E)-2-(3,4-diacetoxybenzyl)-4-(3,4diacetoxyphenylmethyl)but-3-enoate 10, only after acetylation under usual experimental conditions (Scheme 2, Table 1, entry 3). In accordance with previously reported data, ${ }^{20}$ the IBX-de$O$-methylation proceeded by a ionic mechanism during which guaiacyl derivative adds to the iodine(V) center of IBX to give a $\lambda^{5}$-iodanyl intermediate. The intramolecular (and regioselective) delivery of an oxygen atom from the $\lambda^{5}$-iodanyl intermediate leads to a more stable $\lambda^{3}$-iodanyl intermediate that is then hydrolyzed into the corresponding ortho-quinone derivatives and

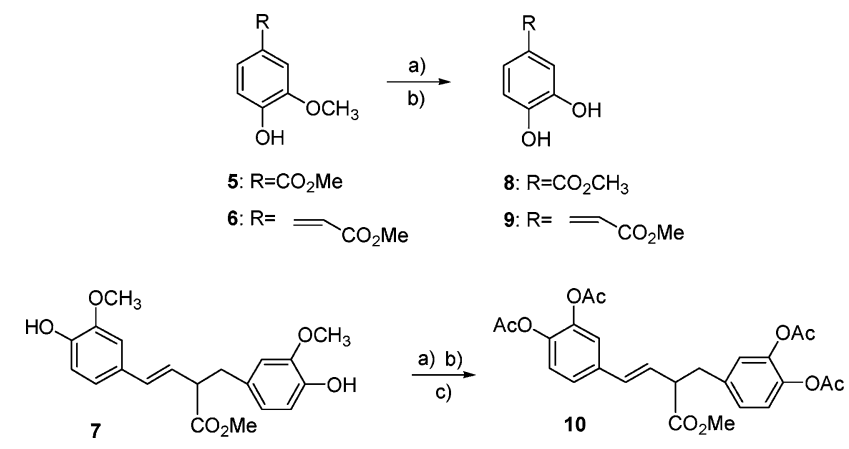

Scheme 2 Oxidation of monolignol derivatives 5-7 by IBX. Reagents and conditions: a) IBX, DMC, $\mathrm{H}_{2} \mathrm{O}$; b) $\mathrm{Na}_{2} \mathrm{~S}_{2} \mathrm{O}_{4}, \mathrm{H}_{2} \mathrm{O}$; c) $\mathrm{Ac}_{2} \mathrm{O}$, py.

2-iodobenzoic acid (IBA), the only by-product of the reaction. Catechols were then obtained during the final reductive step.

Next, we applied the oxidation procedure with IBX to three selected guaiacyl lignan derivatives, 7-hydroxymatairesinol 11 (butyrolactone lignan), $\alpha$-conidendrin 12 (aryltetralin lignan) and lariciresinol 13 (tetrahydrofuran lignan), extracted from knots of Norway Spruce (Picea abies). ${ }^{27}$ The oxidation of lignans 11-13 afforded new catechols 14-16 in acceptable yields, as well as unreacted substrate and some over-oxidation or oligomerization products $^{28}$ that we were not able to recover from the reaction mixture, probably because of their high polarity (Scheme 3, Table 1 , entries 4-6). In these reactions, $\alpha$-conidendrin 12 was the most reactive lignan, affording the catechol derivative $\mathbf{1 5}$ in quantitative conversion and a yield (70\%) higher than the other lignans. The catechol derivatives 15-16 were also acetylated to compounds $\mathbf{1 7 - 1 8}$, as selected examples to compare the biological activity with parent guaiacyl and catechol compounds (vide infra). To the best of our knowledge, this is the first example of synthesis of catechol lignan derivatives through a chemical procedure that mimics the reaction products of cytochrome P-450 activity in the cell.<smiles>COc1cc(C[C@H]2C(=O)OC[C@H]2CO)ccc1O</smiles>

a)<smiles>O=C1OC[C@H](Cc2ccc(O)c(O)c2)[C@@H]1c1ccc(O)c(O)c1</smiles><smiles>COc1cc([C@@H]2c3cc(O)c(OC)cc3C[C@@H]3C(=O)OC[C@H]32)ccc1O</smiles><smiles>O=C1OC[C@H]2Cc3cc(O)c(O)cc3[C@@H](c3ccc(O)c(O)c3)[C@H]12</smiles><smiles>CC(=O)Oc1ccc(C2c3cc(OC(C)=O)c(OC(C)=O)cc3C[C@H]3C(=O)OC[C@H]23)cc1</smiles><smiles>COc1cc(C[C@@H]2CO[C@H](c3ccc(O)c(OC)c3)[C@H]2CO)ccc1O</smiles><smiles>C1=C[C+]2C=CC(=C1)C2</smiles><smiles>OC[C@H]1COC(c2ccc(O)c(O)c2)[C@@H]1Cc1ccc(O)c(O)c1</smiles>

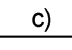<smiles>CC(=O)OC[C@H]1[C@H](Cc2ccc(OC(C)=O)c(OC(C)=O)c2)CO[C@H]1c1ccc(OC(C)=O)c(OC(C)=O)c1</smiles>

18

Scheme 3 Oxidation of lignans 11-13 by IBX. Reagents and conditions: a) IBX, DMC, $\mathrm{H}_{2} \mathrm{O}$; b) $\mathrm{Na}_{2} \mathrm{~S}_{2} \mathrm{O}_{4}, \mathrm{H}_{2} \mathrm{O}$; c) Ac $2 \mathrm{O}$, py. 
To further evaluate the generality of this procedure, we extended the protocol of IBX oxidation to two neolignan derivatives, 19 and 20, in which the phenylpropane units are not bonded into the $\beta$ and $\beta^{\prime}$ positions. Neolignans, which are the most abundant sub-structures in lignin, ${ }^{29}$ are recalcitrant to oxidation processes and usually furnish very complex reaction mixtures under forcing experimental conditions. ${ }^{13 a}$ When freshly prepared 19 was treated with IBX under previously reported experimental conditions, the catechol derivative $\mathbf{2 1}$ was obtained as the only recovered product in acceptable yield in addition to unreacted substrate (Scheme 4, Table 1, entry 7). We were not able to recover the catechol derivative of $\mathbf{2 0}$, which was obtained from the reaction mixture only as a fully acetylated derivative $\mathbf{2 2}$ (Scheme 4, Table 1, entry 8).

The catechol derivatives $8,9,14,15,16,21$ and the acetylated derivatives $10,17, \mathbf{1 8}$, and 22 were evaluated for their toxicity relative to their parent natural compounds 5, 6, 11, 12, 13 and 19 to better define the role of the catechol moiety on structure-activity relationships. In particular, we assessed potential genotoxic effects in mammalian cells in vitro by analyzing the induction of chromosomal aberrations, which are highly predictive of long term genetic and cancer risk. ${ }^{29,30}$ Analyses of the mitotic index (MI), an indirect parameter used to evaluate cytotoxic effects, and proliferative replication index (PRI), used to assess cell division kinetics and interference with cellular check-points, were also determined.<smiles>COc1cc(C(O)COc2ccccc2OC)ccc1O</smiles>

19<smiles>COc1cc(C(O)C(CO)Oc2ccccc2OC)ccc1O</smiles>

20<smiles>COc1ccccc1OCC(O)c1ccc(O)c(O)c1</smiles>

21

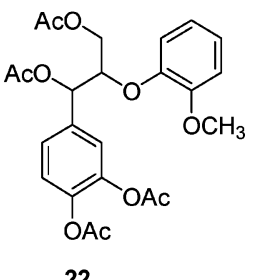

Scheme 4 Oxidation of neolignans 19 and 20 by IBX. Reagents and conditions: a) IBX, DMC, $\mathrm{H}_{2} \mathrm{O}$; b) $\mathrm{Na}_{2} \mathrm{~S}_{2} \mathrm{O}_{4}, \mathrm{H}_{2} \mathrm{O}$; c) $\mathrm{Ac}_{2} \mathrm{O}$, py.

Among the different parent compounds and corresponding catechols and acetylated catechol derivatives, the monolignols methyl vanillate $\mathbf{5}$ and methyl ferulate $\mathbf{6}$ did not induce marked cytotoxicity at any dose-level employed and were not clastogenic. MI and PRI values were only slightly lower $(250$ and $500 \mu \mathrm{M})$ in the cultures treated with methyl ferulate 6 (Tables 2 and 3). No statistically significant increases in the incidence of chromosomal

Table 2 MI values observed in V79 cells for compounds 5 and $\mathbf{8}$

\begin{tabular}{|c|c|c|c|c|c|c|c|c|}
\hline \multirow[b]{2}{*}{ Compound } & \multirow[b]{2}{*}{ Dose level $(\mu \mathrm{M})$} & \multirow[b]{2}{*}{ Mean MI (\%) } & \multirow[b]{2}{*}{ Relative MI } & \multicolumn{3}{|c|}{ Frequency of } & \multirow[b]{2}{*}{ PRI } & \multirow[b]{2}{*}{ Relative PRI } \\
\hline & & & & M1 & M2 & M3 & & \\
\hline None (control, DMSO) & $1 \%$ & 5.2 & 100 & 3 & 96 & 1 & 1.98 & 100 \\
\hline 5 & 25 & 4.6 & 88 & 9 & 91 & 0 & 1.91 & 96 \\
\hline 5 & 50 & 5.1 & 98 & 7 & 93 & 0 & 1.93 & 97 \\
\hline 5 & 100 & 5.5 & 105 & 7 & 93 & 0 & 1.93 & 97 \\
\hline 5 & 250 & 5.1 & 98 & 9 & 91 & 0 & 1.91 & 96 \\
\hline 5 & 500 & 4.0 & 78 & 9 & 91 & 0 & 1.91 & 96 \\
\hline None (control, DMSO) & $1 \%$ & 4.0 & 100 & 25 & 75 & 0 & 1.75 & 100 \\
\hline 8 & 25 & 3.1 & 78 & 44 & 56 & 0 & 1.72 & 98 \\
\hline 8 & 50 & 2.9 & 71 & 30 & 70 & 0 & 1.70 & 97 \\
\hline 8 & 100 & 2.4 & 60 & 37 & 63 & 0 & 1.63 & 93 \\
\hline 8 & 250 & 1.9 & 47 & 48 & 52 & 0 & 1.42 & 81 \\
\hline 8 & 500 & 1.7 & 43 & 95 & 5 & 0 & 1.05 & 60 \\
\hline
\end{tabular}

Table 3 MI values observed in V79 cells for compounds 6 and 9

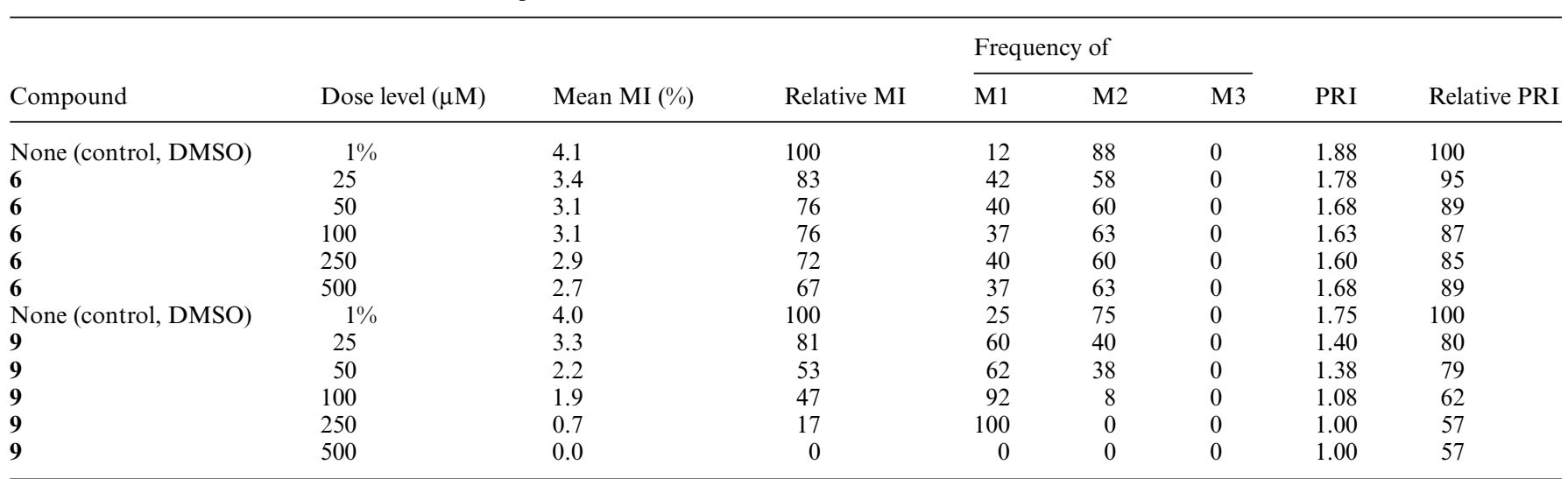


aberrations were observed at any dose-level employed (Fig. 2 and 3). In contrast, their corresponding catechol derivatives, methyl protocatechuate $\mathbf{8}$ and methyl caffeate $\mathbf{9}$, showed marked cytotoxicity and dose-related, statistically significant, increases of chromosomal aberrations (Figs. 2 and 3). MI and PRI values were reduced up to 43 and $60 \%$ respectively by methyl protocatechuate 8 at $500 \mu \mathrm{M}$, and up to 17 and $57 \%$ respectively by methyl caffeate 9

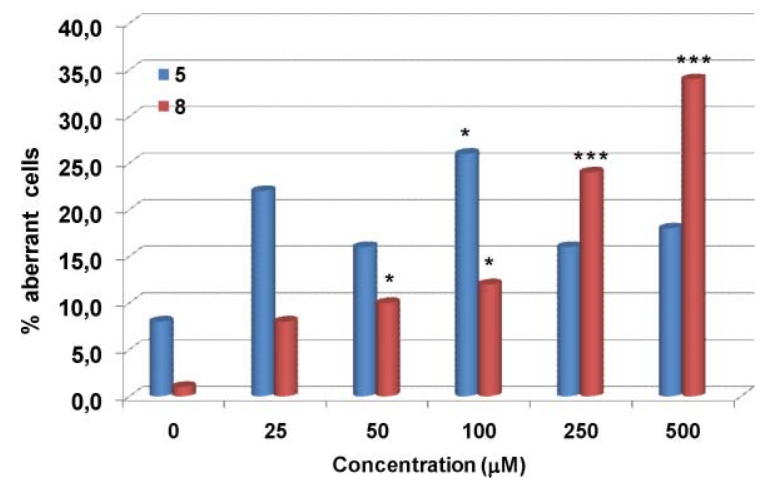

Fig. 2 Frequency of aberration-bearing cells induced by the monolignol methyl vanillate $\mathbf{5}$ and its catechol derivative methyl protocatechuate $\mathbf{8}$ in V79 cells in vitro. ${ }^{*}$ and $* * *$ : Statistically significant at $\mathrm{P}<0.05$ and 0.001 respectively by Fisher's Exact test.

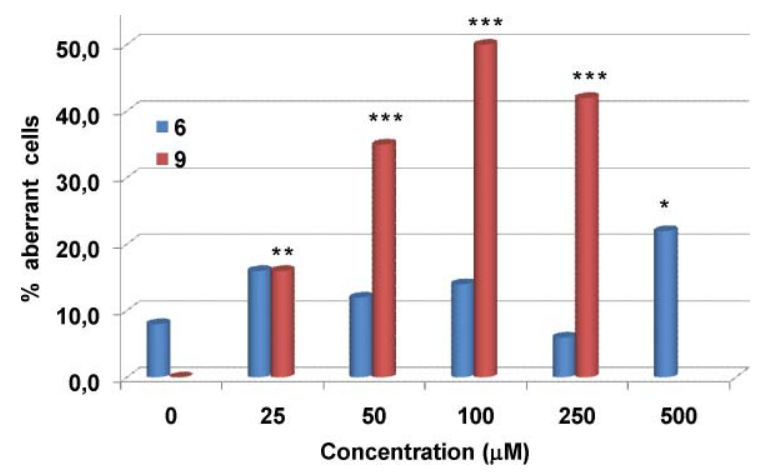

Fig. 3 Frequency of aberration-bearing cells induced by the monolignol methyl ferulate $\mathbf{6}$ and its catechol derivative methyl caffeate $\mathbf{9}$ in V79 cells in vitro. *, ** and ***: Statistically significant at $\mathrm{P}<0.05,0.01$ and 0.001 respectively by Fisher's Exact test. at $250 \mu \mathrm{M}$ compared to the relevant solvent control (Tables 2 and 3). At higher dose-levels, methyl caffeate 9 proved to be severely toxic, and no cytogenetic analysis was performed since no metaphases were recovered (Table 3).

Among the group of lignans assessed, 7-hydroxymatairesinol 11 and lariciresinol 13, similarly to the monolignols methyl vanillate 5 and methylferulate $\mathbf{6}$, did not show marked cytotoxicity and did not induce chromosomal aberrations at any of the doselevels employed (Figs. 4 and 5). MI values were only reduced in 11-treated cultures up to $67 \%$ of the relevant solvent control value at $500 \mu \mathrm{M}$, while PRI values were not affected in either compound (Tables 4 and 5).

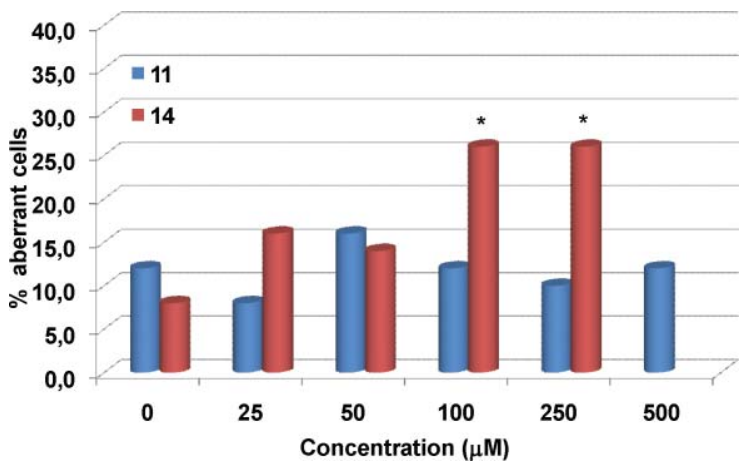

Fig. 4 Frequency of aberration-bearing cells induced by the lignan 7-hydroxymatairesinol 11 and its catechol derivative $\mathbf{1 4}$ in V79 cells in vitro.

*: Statistically significant at $\mathrm{P}<0.05$ by Fisher's Exact test.

Alternatively, the remaining lignan $\alpha$-conidendrin $\mathbf{1 2}$ proved to be a strong clastogenic compound without marked cytotoxicity. It induced statistically significant increases in chromosomal aberrations at 100 and $250 \mu \mathrm{M}$ (Fig. 6) without significant cytotoxicity, since the MI and PRI were not different from the relevant solvent control values (Table 6). However, all the corresponding catechol derivatives in this group showed pronounced clastogenicity (Figs. 4-6) and selective blocking of cell kinetics at M1 metaphases (Tables 4-6). Cytotoxicity was also markedly enhanced, but only in $\mathbf{1 4}$ and 16 were MI values were significantly reduced at higher dose-levels, dropping to zero in the case of catechol derivative $\mathbf{1 4}$ at $500 \mu \mathrm{M}$ (Table 4).

Table 4 MI values observed in V79 cells for compounds $\mathbf{1 1}$ and $\mathbf{1 4}$

\begin{tabular}{|c|c|c|c|c|c|c|c|c|}
\hline \multirow[b]{2}{*}{ Compound } & \multirow[b]{2}{*}{ Dose level $(\mu \mathrm{M})$} & \multirow[b]{2}{*}{ Mean MI (\%) } & \multirow[b]{2}{*}{ Relative MI } & \multicolumn{3}{|c|}{ Frequency of } & \multirow[b]{2}{*}{ PRI } & \multirow[b]{2}{*}{ Relative PRI } \\
\hline & & & & M1 & M2 & M3 & & \\
\hline None (control, DMSO) & $1 \%$ & 4.9 & 100 & 3 & 96 & 1 & 1.98 & 100 \\
\hline 11 & 25 & 4.0 & 82 & 8 & 92 & 0 & 1.92 & 97 \\
\hline 11 & 50 & 4.5 & 92 & 6 & 94 & 0 & 1.94 & 98 \\
\hline 11 & 100 & 4.1 & 84 & 8 & 92 & 0 & 1.92 & 97 \\
\hline 11 & 250 & 4.3 & 88 & 10 & 90 & 0 & 1.90 & 99 \\
\hline 11 & 500 & 3.3 & 67 & 16 & 84 & 0 & 1.92 & 97 \\
\hline None (control. DMSO) & $1 \%$ & 4.1 & 100 & 12 & 82 & 0 & 1.88 & 100 \\
\hline 14 & 25 & 3.4 & 83 & 13 & 87 & 0 & 1.87 & 99 \\
\hline 14 & 50 & 2.6 & 62 & 25 & 75 & 0 & 1.75 & 93 \\
\hline 14 & 100 & 1.4 & 35 & 30 & 70 & 0 & 1.70 & 90 \\
\hline 14 & 250 & 0.9 & 22 & 100 & 0 & 0 & 1.00 & 53 \\
\hline 14 & 500 & 0.0 & 0.0 & 0 & 0 & 0 & 0.00 & 0 \\
\hline
\end{tabular}


Table 5 MI values observed in V79 cells

\begin{tabular}{|c|c|c|c|c|c|c|c|c|}
\hline \multirow[b]{2}{*}{ Compound } & \multirow[b]{2}{*}{ Dose level $(\mu \mathrm{M})$} & \multirow[b]{2}{*}{ Mean MI (\%) } & \multirow[b]{2}{*}{ Relative MI } & \multicolumn{3}{|c|}{ Frequency of } & \multirow[b]{2}{*}{ PRI } & \multirow[b]{2}{*}{ Relative PRI } \\
\hline & & & & M1 & M2 & M3 & & \\
\hline None (control, DMSO) & $1 \%$ & 4.9 & 100 & 3 & 96 & 1 & 1.98 & 100 \\
\hline 13 & 25 & 4.0 & 82 & 6 & 94 & 0 & 1.93 & 82 \\
\hline 13 & 50 & 4.7 & 95 & 3 & 97 & 0 & 1.95 & 95 \\
\hline 13 & 100 & 4.9 & 99 & 3 & 97 & 0 & 1.97 & 99 \\
\hline 13 & 250 & 6.4 & 131 & 5 & 95 & 0 & 1.97 & 131 \\
\hline 13 & 500 & 6.0 & 122 & 7 & 93 & 0 & 1.94 & 122 \\
\hline None (control, DMSO) & $1 \%$ & 4.13 & 100 & 12 & 88 & & 1.98 & 100 \\
\hline 16 & 25 & 3.48 & 84 & 12 & 88 & 0 & 1.88 & 95 \\
\hline 16 & 50 & 3.31 & 80 & 8 & 92 & 0 & 1.92 & 97 \\
\hline 16 & 100 & 2.24 & 54 & 14 & 86 & 0 & 1.86 & 94 \\
\hline 16 & 250 & 2.12 & 51 & 36 & 64 & 0 & 1.64 & 88 \\
\hline 16 & 500 & 0.50 & 12 & 100 & 0 & 0 & 1.00 & 61 \\
\hline None (control, DMSO) & $1 \%$ & 4.13 & 100 & 12 & 88 & 0 & 1.98 & 100 \\
\hline 18 & 25 & 3.62 & 88 & 10 & 90 & 0 & 1.90 & 96 \\
\hline 18 & 50 & 2.55 & 62 & 12 & 88 & 0 & 1.88 & 95 \\
\hline 18 & 100 & 2.50 & 61 & 15 & 85 & 0 & 1.85 & 93 \\
\hline 18 & 250 & 2.39 & 58 & 37 & 63 & 0 & 1.63 & 88 \\
\hline 18 & 500 & 2.10 & 51 & 85 & 15 & 0 & 1.15 & 71 \\
\hline
\end{tabular}

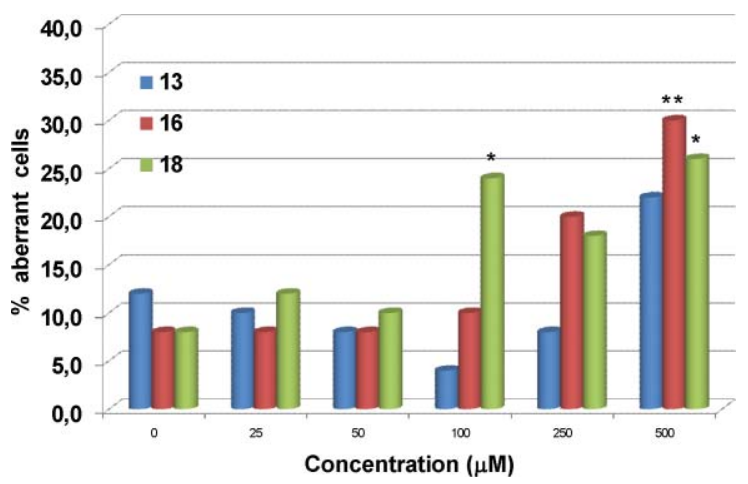

Fig. 5 Frequency of aberration-bearing cells induced by the lignan lariciresinolo 13 and their catechol and acetylated catehcol derivatives $\mathbf{1 6}$ and $\mathbf{1 8}$ respectively in V79 cells in vitro. * and **: Statistically significant at $\mathrm{P}<0.05$ and 0.01 respectively by Fisher's Exact test.

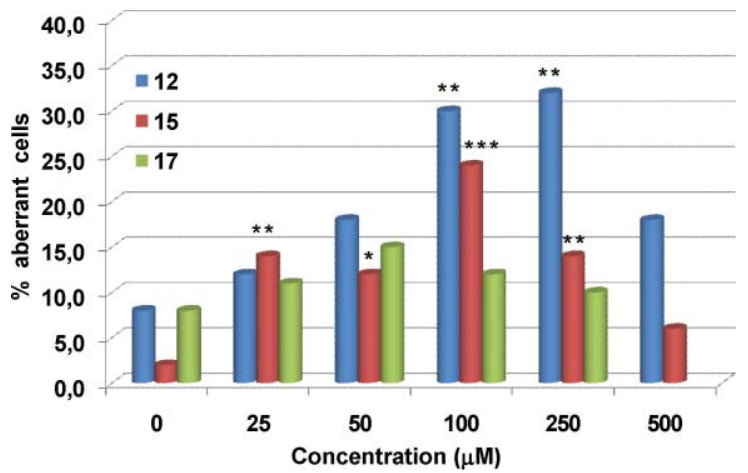

Fig. 6 Frequency of aberration-bearing cells induced by the lignan $\alpha$-conidendrin 12, its catechol derivative $\mathbf{1 5}$ and its acetylated catechol derivative $\mathbf{1 7}$ in V79 cells in vitro. ${ }^{*},{ }^{*}$ and ${ }^{* * *}$ : Statistically significant at $\mathrm{P}<0.05,0.01$ and 0.001 respectively by Fisher's Exact test.

In contrast, compound 15, though it induced selective block of cell cycle kinetic similar to $\mathbf{1 4}$ and $\mathbf{1 6}$, did not prove to be cytotoxic since the MI values were not lower than the relevant solvent control values. This interesting finding indicates that $\mathbf{1 5}$ could trigger specific mitotic check-points located between the onset of mitosis and the activation of the anaphase-promoting complex (APC). This aspect is supported by the significant induction of endoreduplicated cells $(9 \%)$ at $500 \mu \mathrm{M}$ (data not shown). Endoreduplication consists of two successive DNA synthetic rounds without an intervening mitosis stage, leading to the formation of diplochromosomes in the following mitotic metaphases, and thus generating tetraploid and polyploid cells. Polyploid cells are genetically unstable and lose chromosome randomly to give aneuploidy (Fig. 7). As far as the acetylated catechol derivatives were concerned, compound $\mathbf{1 7}$ did not prove to be clastogenic but showed a marked cytotoxicity. MI and PRI values were reduced up to 28 and $53 \%$ of solvent control values at $250 \mu \mathrm{M}$ respectively. At $500 \mu \mathrm{M}$ it was extremely cytotoxic and no metaphases were recovered. Compound $\mathbf{1 8}$ induced a single positive result in terms of induction of chromosomal aberrations at $500 \mu \mathrm{M}$ accompanied by a mild cytotoxicity. MI and PRI values were reduced up to 51 and $71 \%$ of solvent control values at $500 \mu \mathrm{M}$

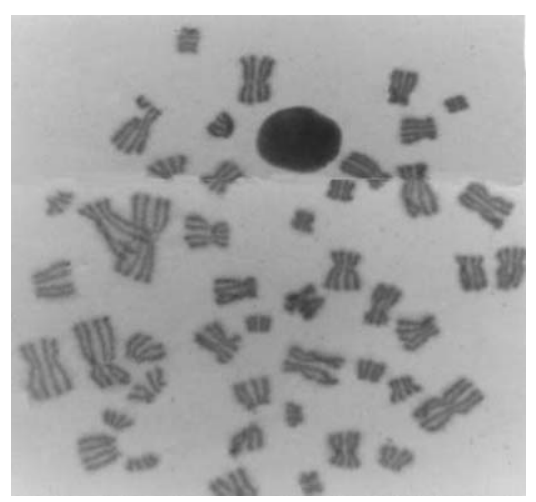

Fig. 7 Endoreduplicated cell from a V79 cell line treated with the catechol derivative $\mathbf{1 5}$ of lignan $\alpha$-conidendrin at $500 \mu \mathrm{M}$. 
Table 6 MI values observed in V79 cells for compounds 12, 15 and 17

\begin{tabular}{|c|c|c|c|c|c|c|c|c|}
\hline \multirow[b]{2}{*}{ Compound } & \multirow[b]{2}{*}{ Dose level $(\mu \mathrm{M})$} & \multirow[b]{2}{*}{ Mean MI (\%) } & \multirow[b]{2}{*}{ Relative MI } & \multicolumn{3}{|c|}{ Frequency of } & \multirow[b]{2}{*}{ PRI } & \multirow[b]{2}{*}{ Relative PRI } \\
\hline & & & & M1 & $\mathrm{M} 2$ & M3 & & \\
\hline None (control, DMSO) & $1 \%$ & 5.2 & 100 & 3 & 96 & 1 & 1.98 & 100 \\
\hline 12 & 25 & 5.0 & 95 & 6 & 94 & 0 & 1.94 & 98 \\
\hline 12 & 50 & 4.5 & 87 & 4 & 96 & 0 & 1.96 & 99 \\
\hline 12 & 100 & 4.7 & 89 & 6 & 94 & 0 & 1.94 & 98 \\
\hline 12 & 250 & 5.8 & 112 & 2 & 98 & 0 & 1.98 & 100 \\
\hline 12 & 500 & 5.6 & 107 & 7 & 93 & 0 & 1.93 & 97 \\
\hline None (control, DMSO) & $1 \%$ & 4.0 & 100 & 12 & 88 & 0 & 1.88 & 100 \\
\hline 15 & 25 & 2.0 & 50 & 32 & 68 & 0 & 1.68 & 89 \\
\hline 15 & 50 & 1.8 & 44 & 35 & 65 & 0 & 1.65 & 88 \\
\hline 15 & 100 & 1.7 & 42 & 45 & 55 & 0 & 1.55 & 82 \\
\hline 15 & 250 & 3.4 & 84 & 81 & 19 & 0 & 1.19 & 63 \\
\hline 15 & 500 & 3.6 & 89 & 95 & 5 & 0 & 1.05 & 56 \\
\hline None (control, DMSO) & $1 \%$ & 4.1 & 100 & 10 & 90 & 0 & 1.9 & 100 \\
\hline 17 & 25 & 3.4 & 82 & 87 & 13 & 0 & 1.21 & 64 \\
\hline 17 & 50 & 2.8 & 68 & 80 & 20 & 0 & 1.20 & 63 \\
\hline 17 & 100 & 2.3 & 54 & 99 & 1 & 0 & 1.01 & 53 \\
\hline 17 & 250 & 1.2 & 28 & 100 & 0 & 0 & 1.00 & 53 \\
\hline 17 & 500 & 0.0 & 0 & 0 & 0 & 0 & 0.0 & 0 \\
\hline
\end{tabular}

Table 7 MI values observed in V79 cells

\begin{tabular}{|c|c|c|c|c|c|c|c|c|}
\hline \multirow[b]{2}{*}{ Compound } & \multirow[b]{2}{*}{ Dose level $(\mu \mathrm{M})$} & \multirow[b]{2}{*}{ Mean MI (\%) } & \multirow[b]{2}{*}{ Relative MI } & \multicolumn{3}{|c|}{ Frequency of } & \multirow[b]{2}{*}{ PRI } & \multirow[b]{2}{*}{ Relative PRI } \\
\hline & & & & M1 & M2 & M3 & & \\
\hline None (control, DMSO) & $1 \%$ & 4.9 & 100 & 3 & 96 & 1 & 2.0 & 100 \\
\hline 19 & 25 & 5.1 & 104 & 4 & 96 & 0 & 1.9 & 97 \\
\hline 19 & 50 & 4.1 & 84 & 3 & 97 & 0 & 2.0 & 98 \\
\hline 19 & 100 & 4.2 & 85 & 4 & 96 & 0 & 2.0 & 99 \\
\hline 19 & 250 & 4.7 & 96 & 4 & 96 & 0 & 2.0 & 99 \\
\hline 19 & 500 & 4.3 & 88 & 10 & 90 & 0 & 1.9 & 97 \\
\hline None (control, DMSO) & $1 \%$ & 4.0 & 100 & 25 & 75 & 0 & 1.8 & 100 \\
\hline 21 & 25 & 1.7 & 42 & 45 & 55 & 0 & 1.6 & 89 \\
\hline 21 & 50 & 1.7 & 43 & 60 & 40 & 0 & 1.4 & 80 \\
\hline 21 & 100 & 1.4 & 34 & 90 & 10 & 0 & 1.1 & 63 \\
\hline 21 & 250 & 1.2 & 29 & 100 & 0 & 0 & 1.0 & 57 \\
\hline 21 & 500 & 0.4 & 10 & 100 & 0 & 0 & 1.0 & 57 \\
\hline
\end{tabular}

respectively (Table 6). Furthermore, the catechol derivative $\mathbf{2 1}$ of neolignan 19 showed a similar pattern of results observed for the corresponding catechol of monolignols $\mathbf{5}$ and $\mathbf{6}$ and lignans 11, 12 and 13 (Table 7). It induced dose-related and statistically significant increases in chromosomal aberrations at all dose-levels assayed (Fig. 8) accompanied by marked cytotoxicity. MI values were reduced up to $10 \%$ of the relevant solvent control value at $500 \mu \mathrm{M}$ while the PRI was reduced to $63 \%$ at $100 \mu \mathrm{M}$, and up to $57 \%$ at 250 and $500 \mu \mathrm{M}$, where only metaphase 1 (M1) was observed.

\section{Experimental}

\section{Chemical section}

Reagents and lignans. All solvents and reagents used were of analytical grade and were purchased from Aldrich Chemical Co. Silica gel 60 F254 plates and silica gel 60 were furnished from Merck. IBX was prepared in laboratory as described in the literature. ${ }^{18}$ Guaiacyl derivative 3 and lignan derivatives 11, 12 and 13 were purchased from Oy ArboNova Ab. Neolignans 19

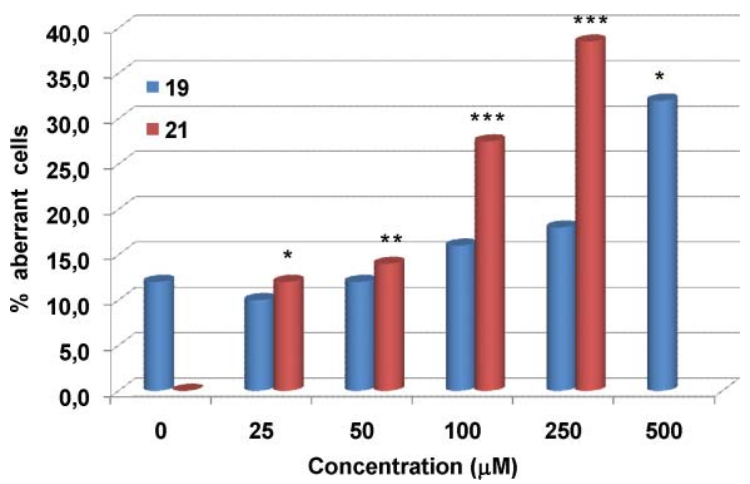

Fig. 8 Frequency of aberration-bearing cells induced by the neolignan 19 and its catechol derivative 21 in V79 cells in vitro. ${ }^{*},{ }^{* *}$ and ${ }^{* * *}$ : Statistically significant at $\mathrm{P}<0.05,0.01$ and 0.001 respectively by Fisher's Exact test.

and 20 were synthesized according to the reported literature. ${ }^{31}$ Methyl esters 5, 6, and 7 were prepared as described in the literature..$^{23-25}$ The nomenclature of lignans and neolignans has been assigned according to the IUPAC-IUB Joint Commission 
on Biochemical Nomenclature (JCBN), Recommendations (2000)

Oxidation with IBX. Preparation of catecholic compounds. Substrate $(1.0 \mathrm{mmol})$ was dissolved in dimethyl carbonate-water 9:1 (10 ml) and then IBX (1.2 eq.) was added, and the mixture stirred at room temperature for 3-5 $\mathrm{h}$, depending on the substrate. At the end, water $(10 \mathrm{ml})$ and $\mathrm{Na}_{2} \mathrm{~S}_{2} \mathrm{O}_{4}(2.4$ eq.) were added and the solution was stirred for 5-10 minutes. After evaporation of the solvent under vacuum, the residue was solubilized with ethyl acetate $(20 \mathrm{ml})$ and treated with a saturated solution of $\mathrm{NaHCO}_{3}$ $(10 \mathrm{ml})$. The aqueous phase was extracted with ethyl acetate $(3 \times 10 \mathrm{ml})$. The organic phases were washed with a saturated solution of $\mathrm{NaCl}(20 \mathrm{ml})$ and dried over $\mathrm{Na}_{2} \mathrm{SO}_{4}$. After evaporation of the solvent, catecholic lignan derivatives 8, 9, 14, 15, 16, and 21 were isolated by chromatographic purification on silica gel by using ethyl acetate-hexane (ratio 1:2, 2:1, 3:1 depending on the compound) as eluent.

Preparation of methyl (3E)-2-(3,4-diacetoxybenzyl)-4-(3,4diacetoxyphenyl)but-3-enoate (10). The substrate (1.0 mmol) was dissolved in dimethyl carbonate-water 9:1 (10 ml) and then IBX (1.2 eq.) was added at room temperature for 3-5 $\mathrm{h}$ depending on the substrate. At the end, water $(10 \mathrm{ml})$ and $\mathrm{Na}_{2} \mathrm{~S}_{2} \mathrm{O}_{4}$ (2.4 eq.) were added and the solution was stirred for 5-10 minutes. After evaporation of the solvent under vacuum, the residue was solubilized with ethyl acetate $(20 \mathrm{ml})$ and treated with $1 \mathrm{M} \mathrm{HCl}$ $(10 \mathrm{ml})$. The aqueous phase was extracted with ethyl acetate $(3 \times$ $10 \mathrm{ml})$. The organic phases were washed with a saturated solution of $\mathrm{NaCl}(10 \mathrm{ml})$ and dried over $\mathrm{Na}_{2} \mathrm{SO}_{4}$. After evaporation of the solvent, the mixture reaction was solubilized in pyridine $(10 \mathrm{ml})$, acetic anhydride $(10 \mathrm{ml})$ was added, and the mixture stirred overnight. At the end of the reaction, a $1 \mathrm{M}$ solution of $\mathrm{HCl}$ $(10 \mathrm{ml})$ was added and the final products were extracted with ethyl acetate $(3 \times 10 \mathrm{ml})$. The organic phases were washed with a saturated solution of $\mathrm{HCl}(20 \mathrm{ml})$ and with a saturated solution of $\mathrm{NaCl}(20 \mathrm{ml})$, then dried over $\mathrm{Na}_{2} \mathrm{SO}_{4}$. After evaporation of the solvent, and chromatographic purification on silica gel, acetylated compound $\mathbf{1 0}$ was isolated.

Acetylation of catecholic compounds. Substrate $(1.0 \mathrm{mmol})$ was solubilized in pyridine $(10 \mathrm{ml})$, acetic anhydride $(10 \mathrm{ml})$ was added, and the mixture stirred overnight. At the end of the reaction, a $1 \mathrm{M}$ solution of $\mathrm{HCl}(10 \mathrm{ml})$ was added and the final products were extracted with ethyl acetate $(3 \times 10 \mathrm{ml})$. The organic phases were washed with a saturated solution of $\mathrm{HCl}(20 \mathrm{ml})$ and with a saturated solution of $\mathrm{NaCl}(20 \mathrm{ml})$, then dried over $\mathrm{Na}_{2} \mathrm{SO}_{4}$. After evaporation of the solvent, and chromatographic purification on silica gel, acetylated compounds 17,18 and 22 were isolated.

Identification and characterization of oxidation products. ${ }^{1} \mathrm{H}$ NMR and ${ }^{13} \mathrm{C}$ NMR were recorded on a Bruker $200 \mathrm{MHz}$ spectrometer using $\mathrm{CDCl}_{3}\left(99.8 \%\right.$ in deuterium), $\mathrm{CD}_{3} \mathrm{OD}(99.8 \%$ in deuterium) or $\mathrm{CD}_{3} \mathrm{COCD}_{3}(99.8 \%$ in deuterium) as solvents. All chemical shifts are expressed in parts per million ( $\delta$ scale $)$ and coupling constants in Hertz $(\mathrm{Hz})$. HR-MS were recorded with a Micromass Q-TOF micro mass spectrometer (Waters).

Methyl 4-hydroxy-3-methoxybenzoate (Methyl vanillate, 5). Solid. Yield 93\%. Mp $70{ }^{\circ} \mathrm{C}^{24}$
Methyl 4-hydroxy-3-methoxycinnamate (Methyl ferulate, 6). Solid. Yield $70 \%$. Mp $66^{\circ} \mathrm{C} .{ }^{25}$

Methyl (3E)-4-(4-hydroxy-3-methoxyphenyl)-2-(4-hydroxy-3methoxyphenylmethyl)but-3-enoate (7). Solid. Yield 88\%. ${ }^{23}$

Methyl 3,4-dihydroxybenzoate (Methyl protocatechuate 8). Solid. Yield $73 \%$. Mp $135^{\circ} \mathrm{C} .{ }^{25}$

Methyl (2E)-3-(3,4-dihydroxyphenyl)prop-2-enoate (Methyl caffeate 9). Solid. Yield $82 \% . \mathrm{Mp} 159{ }^{\circ} \mathrm{C} .{ }^{25}$

Methyl (3E)-2-(3,4-diacetoxybenzyl)-4-(3,4-diacetoxyphenyl)but-3-enoate (10). Solid. Yield $25 \%$. Mp $144{ }^{\circ} \mathrm{C} .{ }^{23} \delta_{\mathrm{H}}(200 \mathrm{MHz}$, $\left.\mathrm{CDCl}_{3}\right) \delta: 2.25(6 \mathrm{H}, \mathrm{s}, 2 \mathrm{xMe}), 2.26(3 \mathrm{H}, \mathrm{s}, \mathrm{Me}), 2.27$ (3H, s, Me), 2.81-2.92 (1H, dd, $\left.J_{l}=13.7 \mathrm{~Hz}, J_{2}=6.9 \mathrm{~Hz}, \mathrm{H}-7 \mathrm{a}^{\prime \prime}\right), 3.07-3.18$ $\left(1 \mathrm{H}, \mathrm{dd}, J_{1}=14.0 \mathrm{~Hz}, J_{2}=8.0 \mathrm{~Hz}, \mathrm{H}-7 \mathrm{~b}^{\prime \prime}\right), 3.36-3.47(1 \mathrm{H}, \mathrm{m}$, $\mathrm{H}-2), 3.64(3 \mathrm{H}, \mathrm{s}, \mathrm{OMe}), 6.06-6.18\left(1 \mathrm{H}, \mathrm{dd}, J_{l}=15.9 \mathrm{~Hz}, J_{2}=\right.$ $8.4 \mathrm{~Hz}, \mathrm{H}-3), 6.31-6.38$ (1H, d, $J=15.7 \mathrm{~Hz}, \mathrm{H}-4), 7.04-7.19(6 \mathrm{H}$, m, H-2 $\left., 2^{\prime \prime}, 5^{\prime}, 5^{\prime \prime}, 6^{\prime}, 6^{\prime \prime}\right) ; \delta_{\mathrm{C}}\left(50 \mathrm{MHz}, \mathrm{CDCl}_{3}\right) 20.2$ (2× OAc), 20.6 $(2 \times \mathrm{OAc}), 38.1(\mathrm{C}-1), 50.8(\mathrm{OMe}), 52.0(\mathrm{C}-2), 121.0\left(\mathrm{C}-2^{\prime}\right), 123.2$ (C-2"), 123.4 (C-3), 124.0 (C-5'), /124.7 (C-5'), 127.2 (C-6'), 127.6 (C-6"), 131.4 (C-4), 135.5 (C-1' $), 137.2$ (C-1'), 140.6 (C-3'), 141.4 (C-3"), 141.8 (C-4'), 142.1 (C-4"), 168.2 (4 × OCOMe), 173.2 (COOMe). HR-MS m/z: $498.47864\left(\mathrm{M}^{+}\right)$.

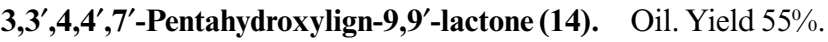
$[\alpha]^{20}{ }_{\mathrm{D}}-4.5^{\circ}$ ( $c 0.5$, acetone). $\delta_{\mathrm{H}}\left(200 \mathrm{MHz}, \mathrm{CDCl}_{3}\right) 2.43-3.11(4 \mathrm{H}$, m, H-7,8,8'), 3.88-3.98 (3H, m, H-7',9a',9b'), 6.47-6.59 (2H, m, H-5, $\left.6^{\prime}\right), 6.64(1 \mathrm{H}, \mathrm{d}, J=2.1, \mathrm{H}-6) 6.70-6.78\left(3 \mathrm{H}, \mathrm{m}, \mathrm{H}-2,2^{\prime}, 5\right) ; \delta_{\mathrm{C}}$ (50 $\left.\mathrm{MHz}, \mathrm{CDCl}_{3}\right) 31.7$ (C-7), 41.2 (C-8), 43.9 (C-8'), 70.5 (C-9'), $76.6\left(\mathrm{C}-7^{\prime}\right), 115.7\left(\mathrm{C}-2^{\prime}\right), 115.9\left(\mathrm{C}-5^{\prime}\right), 116.4(\mathrm{C}-2), 117.8\left(\mathrm{C}-6^{\prime}\right)$, 120.6 (C-5), 122.5 (C-6), 127.9 (C-1), 131.4 (C-1'), 144.1 (C-4), 144.7 (C-3'), 145.5 (C-3), 145.7 (C-4'), 178.3 (C-9). HR-MS m/z: $346.33737\left(\mathrm{M}^{+}\right)$.

$\mathbf{3}^{\prime}, \mathbf{4 , 4}, \mathbf{4}$-Tetrahydroxy-2,7'-cyclolignan-9,9'-lactone (15). Oil. Yield $70 \% .^{32}[\alpha]^{20}{ }_{\mathrm{D}}-75.0^{\circ}$ (c 0.5 , acetone). $\delta_{\mathrm{H}}\left(200 \mathrm{MHz}, \mathrm{CDCl}_{3}\right.$ ) 2.56-3.02 (4H, m, H-7a,7b,8,8'), 3.87-4.06 (3H, m, H-7',9a',9b'), $6.23(1 \mathrm{H}, \mathrm{s}, \mathrm{H}-6), 6.54-6.66\left(3 \mathrm{H}, \mathrm{m}, \mathrm{H}-2^{\prime}, 3,6^{\prime}\right), 6.79(1 \mathrm{H}, \mathrm{d}, J=$ $\left.7.9 \mathrm{~Hz}, \mathrm{H}-5^{\prime}\right) ; \delta_{\mathrm{C}}\left(50 \mathrm{MHz}, \mathrm{CDCl}_{3}\right) 25.1(\mathrm{C}-7), 46.1\left(\mathrm{C}-8^{\prime}\right), 52.0(\mathrm{C}-$ 8), 54.2 (C-7'), 76.4 (C-9'), 120.4 (C-2'), 120.8 (C-6), 121.0 (C-3), $124.2\left(\mathrm{C}-5^{\prime}\right), 125.2$ (C-6'), $131.6(\mathrm{C}-1), 136.2\left(\mathrm{C}-1^{\prime}\right), 140.2$ (C-2), 148.5 (C-5), 148.9 (C-4'), 149.2 (C-3'), 150.4 (C-4), 181.8 (C-9). HR-MS m/z: $328.32211\left(\mathrm{M}^{+}\right)$.

3,3',4,4',9-Pentahydroxy-7,9'-epoxylignan (16). Oil. Yield $40 \%$. $[\alpha]^{20}{ }_{\mathrm{D}}+46.7^{\circ}$ (c 0.1 , acetone). $\delta_{\mathrm{H}}\left(200 \mathrm{MHz}, \mathrm{CDCl}_{3}\right)$ 2.25-2.81 (4H, m, H-7a' $\left.7 \mathrm{~b}^{\prime}, 8,8^{\prime}\right), 3.59-3.67$ (2H, m, H-9a,9b), 3.78-3.91 (2H, m, H-9a',9b'), $4.74(1 \mathrm{H}, \mathrm{d}, J=5.7 \mathrm{~Hz}, \mathrm{H}-7)$, 6.49-6.83 (6H, m, H-2, $\left.2^{\prime}, 5,5^{\prime}, 6,6^{\prime}\right) ; \delta_{\mathrm{C}}\left(50 \mathrm{MHz} \mathrm{CDCl}_{3}\right) 36.2$ (C-7'), 46.3 (C-8'), 57.3 (C-8), 63.4 (C-9), 76.1 (C-9'), 86.1 (C-7), 116.8 (C-5), 118.7 (C-2), 119.1 (C-2'), 119.5 (C-5'), 121.0 (C-6), 123.7 (C-6'), 136.7 (C-1), 140.2 (C-1'), 147.1 (C-4'), 147.8 (C-3), 148.7 (C-4), 148.8 (C-3'). HR-MS m/z: $332.12599\left(\mathrm{M}^{+}\right)$.

2,7'-Cyclolignan-9,9'-lactone-4,5,3', $\mathbf{4}^{\prime}$-tetrayl-tetraacetate (17). Oil. Yield $70 \%$. $[\alpha]^{20}{ }_{\mathrm{D}}-85.0^{\circ}$ (c 0.5 , acetone). $\delta_{\mathrm{H}}\left(200 \mathrm{MHz}, \mathrm{CDCl}_{3}\right.$ ) 2.19 (3H, s, OAc), 2.25 (6H, s, OAc), 2.26 (3H, s, OAc), 2.48-2.61 $\left(2 \mathrm{H}, \mathrm{m}, \mathrm{H}-8,8^{\prime}\right), 2.92-3.05(1 \mathrm{H}, \mathrm{m}, \mathrm{H}-7 \mathrm{a}), 3.22-3.32$ (1H, m, H7b), 3.96-4.30 (3H, m, H-7', 9',9b'), $6.71(1 \mathrm{H}, \mathrm{s}, \mathrm{H}-6), 6.95-7.05$ $\left(3 \mathrm{H}, \mathrm{m}, \mathrm{H}-3,5^{\prime}, 6^{\prime}\right), 7.15\left(1 \mathrm{H}, \mathrm{d}, J=8.2 \mathrm{~Hz}, \mathrm{H}-2^{\prime}\right) ; \delta_{\mathrm{C}}(50 \mathrm{MHz}$, 
$\mathrm{CDCl}_{3}$ ) 20.5 (OAc), 20.6 (OAc), 20.7 (OAc), 29.2 (C-7), 41.4 (C$\left.8^{\prime}\right), 47.2$ (C-8), 49.7 (C-7'), 71.4 (C-9'), 123.3 (C-2'), 124.2 (C-6), 124.4 (C-5'), 126.2 (C-3), 133.8 (C-6'), 136.3 (C-1), 140.0 (C-2), 140.7 (C-4), 141.0 (C-1'), 141.5 (C-4'), 141.5 (C-5), 142.5 (C-3'), 167.9 (OCOMe), 168.1 (OCOMe), 168.3 (OCOMe), 176.0 (C-9). HR-MS m/z: $496.47143\left(\mathrm{M}^{+}\right)$.

(7,9'-Epoxylignan-3,3',4,4',9-pentayl)pentaacetate (18). Oil. Yield $85 \%$. $[\alpha]^{20}{ }_{\mathrm{D}}+12.5^{\circ}$ (c 0.4 , acetone). $\delta_{\mathrm{H}}\left(200 \mathrm{MHz}, \mathrm{CDCl}_{3}\right)$ $1.54(3 \mathrm{H}, \mathrm{s}, \mathrm{OAc}), 2.26(12 \mathrm{H}, \mathrm{s}, 3 \mathrm{xOAc}), 2.43-2.86(4 \mathrm{H}, \mathrm{m}$, $\left.\mathrm{H}-7 \mathrm{a}^{\prime}, 7 \mathrm{~b}^{\prime}, 8,8^{\prime}\right), 4.03-4.31\left(4 \mathrm{H}, \mathrm{m}, \mathrm{H}-9 \mathrm{a}^{\prime}, 9 \mathrm{~b}^{\prime}\right), 4.85(1 \mathrm{H}, \mathrm{d}, J=$ $5.4 \mathrm{~Hz}, \mathrm{H}-7), 6.73-7.15\left(6 \mathrm{H}, \mathrm{m}, \mathrm{H}-2,2^{\prime}, 5,5^{\prime}, 6,6^{\prime}\right) ; \delta_{\mathrm{C}}(50 \mathrm{MHz}$, $\left.\mathrm{CDCl}_{3}\right) 20.6$ (OAc), 20.8 (OAc), 32.8 (C-7'), 41.7 (C-8'), 49.0 (C-8), 62.4 (C-9), 72.6 (C-9'), 82.2 (C-7), 120.6 (C-2'), 123.3 (C-2), 123.4 (C-5'), 123.5 (C-5), 123.6 (C-6), 126.7 (C-6'), 138.6 (C-1), 138.6 (C-1'), 141.6 (C-3), 141.6 (C-3'), 142.0 (C-4), 142.0 (C-4'), 168.1 (OCOMe), 168.2 (OCOMe), 168.3 (OCOMe), 170.9 (OCOMe). HR-MS m/z: $542.54067\left(\mathrm{M}^{+}\right)$.

2-(2'-Methoxyphenoxy)-1-(3",4"-dihydroxyphenyl)ethanol (21). Oil. Yield $85 \% . \delta_{\mathrm{H}}\left(200 \mathrm{MHz}, \mathrm{CDCl}_{3}\right) 3.80(3 \mathrm{H}, \mathrm{s}, \mathrm{OMe}), 3.89-4.06$ (2H, m, H-2a,2b), 4.86-4.93 (1H, m, H-1), 6.79-7.01 (7H, m, H$\left.3^{\prime}, 4^{\prime}, 5^{\prime}, 6^{\prime}, 2^{\prime \prime}, 5^{\prime \prime}, 6^{\prime \prime}\right) ; \delta_{\mathrm{C}}\left(50 \mathrm{MHz}, \mathrm{CDCl}_{3}\right) 56.1(\mathrm{OMe}), 72.4(\mathrm{C}-2)$, 76.2 (C-1), 113.4 (C-2"), 114.3 (C-5"), 115.6 (C-3'), 115.8 (C-6'), $118.6\left(\mathrm{C}-6^{\prime \prime}\right), 121.7\left(\mathrm{C}-5^{\prime}\right), 122.3\left(\mathrm{C}-4^{\prime}\right), 134.3\left(\mathrm{C}-1^{\prime \prime}\right), 145.1\left(\mathrm{C}-3^{\prime \prime}\right)$, $145.5\left(\mathrm{C}-4^{\prime \prime}\right), 149.6\left(\mathrm{C}-2^{\prime}\right), 150.9\left(\mathrm{C}-1^{\prime}\right)$. HR-MS m/z: 276.28969 $\left(\mathrm{M}^{+}\right)$.

2-(2'-Methoxyphenoxy)-1-(3", $\mathbf{4}^{\prime \prime}$-diacetoxyphenyl)propan-1,3diacetate (22). Oil. Yield $70 \% . \delta_{\mathrm{H}}\left(200 \mathrm{MHz}, \mathrm{CDCl}_{3}\right) 1.98(3 \mathrm{H}$, $\mathrm{s}, \mathrm{OAc}), 2.18$ (6H, s, OAc), 2.21 (3H, s, OAc), 3.79 (3H, s, OMe), $4.04-4.28$ (2H, m, H-3a,3b), 4.37-4.46 (1H, m, H-1), 6.06-6.26 $\left(1 \mathrm{H}, \mathrm{m}, \mathrm{H}-3^{\prime}\right), 6.83-7.26\left(6 \mathrm{H}, \mathrm{m}, \mathrm{H}-2^{\prime \prime}, 4^{\prime}, 5^{\prime}, 5^{\prime \prime} 6^{\prime}, 6^{\prime \prime}\right) ; \delta_{\mathrm{C}}(50 \mathrm{MHz}$, $\mathrm{CDCl}_{3}$ ) 20.4 (OAc), 20.6 (OAc), 20.9 (OAc), 55.7 (OMe), 62.2 (C-3), 73.8 (C-1), 80.1 (C-2), 112.0 (C-3'), 118.7 (C-6'), 120.0 (C$\left.5^{\prime}\right), 120.8\left(\mathrm{C}-4^{\prime}\right), 120.9$ (C-2"), $122.4\left(\mathrm{C}-5^{\prime \prime}\right), 123.8$ (C-6" $), 135.2$ $\left(\mathrm{C}-1^{\prime \prime}\right), 141.9$ (C-4"), 142.0 (C-3"), $147.7\left(\mathrm{C}-1^{\prime}\right), 151.2\left(\mathrm{C}-2^{\prime}\right)$, 167.8 (OCOMe), 169.1 (OCOMe), 170.5 (OCOMe). HR-MS m/z: $474.46531\left(\mathrm{M}^{+}\right)$.

\section{Biological section}

Test compounds. All lignans and derivatives were prepared immediately before treatment in dimethyl sulfoxide (DMSO) obtained from Sigma-Aldrich and added to the culture medium such that the final concentration of solvent did not exceed $1 \%$. 5-Bromo-2'-deoxyuridine (BrdU) used to evaluate the frequency of cells in first (M1), second (M2) and third (M3) cell division, and Colcemid to accumulate cells in metaphase, were also purchased from Sigma-Aldrich.

Test systems and culture conditions. Chinese hamster V79 cells were originally obtained from Dr. J. Williamson (British American Tobacco, UK). The karyotype, generation time, plating efficiency, and absence of mycoplasmal contamination were checked at regular intervals. Permanent stocks of V-79 cells were stored in liquid nitrogen $\left(-170{ }^{\circ} \mathrm{C}\right)$ and subcultures are prepared from these stocks for experimental use. At the end of assay the cells were discarded and a new ampoule (containing cells from the stock under liquid nitrogen) was used. In our case experiments on different compounds have been conducted on different days using cells from the same frozen stocks but thawed on different days. Mitotic indices observed in the vehicle controls $(0 \mu \mathrm{M})$ were in the range 4.0-5.2. This slight variation is considered "physiological" and is compatible with our historical control range values. Cultures of the cells are grown in Eagle minimal essential medium (EMEM) supplemented with 10\% Foetal Calf Serum, 2 mM L-Glutamine and antibiotics ( $1 \% \mathrm{w} / \mathrm{v}$ Penicillin and $86 \mu \mathrm{M}$ Streptomycin). All incubations were at $37^{\circ} \mathrm{C}$ in a $5 \%$ carbon dioxide atmosphere and $100 \%$ nominal humidity.

Chromosomal aberration assays. Test compound treatments of Chinese hamster V79 cells were performed in the absence of rat liver metabolism. The study was designed to comply with the experimental methods indicated in the OECD Guidelines for the Testing of Chemicals No. 487 (Draft June 2004).

Following dose-range finding experiments, the assay was performed using dose levels of 500, 250, 100, 50, and $25 \mu \mathrm{M}$ and a three hour treatment time. Solvent-treated cells served as negative control. At the end of treatment ( 3 hours), cultures were washed twice with a PBS solution and re-incubated at $37{ }^{\circ} \mathrm{C}$ in fresh complete culture medium for further 18 hours (approximately 1.5 cell cycle). Cultures set up for analysis of proliferative replication index (PRI) received also BrdU at $9.8 \mu \mathrm{M}$ to differentiate sister chromatids. Colcemid at $0.27 \mu \mathrm{M}$ was added during the last 3 hours of culture to accumulate cells in metaphase. Hypotonic shock was induced by $1 \%$ trisodium citrate solution for 10 minutes. Cell suspension was fixed in a mixture of methanol and glacial acetic acid (v/v 3:1) followed by three washes. Cytogenetic preparations for analyses of chromosomal aberrations and mitotic indices were stained with an aqueous solution of Giemsa $1 \%$. The fluorescence-plus-Giemsa (FPG) technique ${ }^{33}$ was used for sister chromatid differentiation (SCD) staining. Slides were stained for $20 \mathrm{~min}$ with Hoechst $33258(5 \mu \mathrm{g} / \mathrm{ml})$, mounted in saline sodium citrate buffer (SSC) $2 \mathrm{X}$ powder (Anidra Company), and exposed to "black light" for $20 \mathrm{~min}$ at $50{ }^{\circ} \mathrm{C}$. Finally, cells were stained with Giemsa and air-dried for evaluation of the frequency of cells in their first (M1), second (M2) and third (M3) cell division.

Cell division kinetics was determined by the proliferative replication index (PRI) according to the formula: ${ }^{34}$

$$
\mathrm{PRI}=\frac{(1 \times \mathrm{M} 1)+(2 \times \mathrm{M} 2)+(3 \times \mathrm{M} 3)}{100}
$$

where M1, M2, and M3 are the proportions of first, second and third generations of mitotic cells respectively.

To evaluate the mitotic index (MI), cytogenetic preparations stained by Giemsa were analyzed in a light microscope at $400 \times$ magnification. MI was expressed as number of metaphases per 1000 nuclei analyzed.

Scoring for chromosomal damage was undertaken blind with coded slides. A minimum of 100 metaphases per culture were scored for chromosomal aberrations. Chromosomal aberrations were classified as chromatid-type gaps, chromatid-type breaks, chromatid-type exchanges, chromosome-type gaps, chromosometype breaks, chromosome-type exchanges and isolocus events (which include isochromatid and isolocus breaks when these cannot be distinguished), as described by Savage ${ }^{35}$.

For the chromosome aberration assay the number of aberrationbearing cells (excluding gaps) was utilized for statistical analyses. 
To determine the statistical significance Fisher's exact test was used. The test substance is considered positive when statistically significant increases in aberration-bearing cells are observed at two consecutive dose-levels or at the higher dose-level and exceed the historical control mean values.

\section{Conclusions}

In this paper we have described a general and selective procedure for the de- $O$-methylation of guaiacyl monolignols, lignans and neolignans to the corresponding catechol derivatives by a modification of the Quideau demethylation reaction ${ }^{20}$ here performed in an aqueous (green) solvent system. To the best of our knowledge, this is the first example of an oxidative system able to mimic one of the activities of cytochrome P-450 enzymes in the metabolic pathway of the guaiacyl moiety in the cell. Reactions proceeded with satisfactory conversions of substrate and yield of products, even for such recalcitrant substrates as neolignans. In some selected examples, the novel catechol derivatives were also acetylated to afford the corresponding esters as useful references to compare the biological activity with parent compounds. The catechols and the acetylated derivatives were evaluated for the toxicity in comparison to the parent natural compounds. The results obtained indicate that the presence of the catechol moiety sharply enhances the clastogenic potential, the cytotoxicity and the modulation of cell cycle progression. In contrast, acetylated derivatives showed a markedly reduced clastogenic activity, but preserving the cytotoxicity and the modulation of cell cycle progression. The only exception to this general trend was the catechol derivative of $\alpha$-conidendrin, for which cytotoxicity was not observed, thus conferring the property to induce a new effect, the enderoduplication process. Thus, despite the in vitro antioxidant activity usually described for catechol derivatives, our results show for the first time the generation of a clastogenic potential (e.g. induction of chromosomal aberrations), highly indicative of a long-term genetic and cancer risk.

\section{Acknowledgements}

The authors like to thank Interuniversity Consortium Chemistry for the Environment (INCA) for financial support. PNR-FIRB, ASI and EU COST CM07035 System Chemistry are also acknowledged.

\section{References}

1 D. C. Ayres, and J. D. Loike, in Lignans: Chemical, biological and clinical properties, Cambridge University Press, 1990.

2 See as a general review: T. Osawa, in Phenolic Compounds in Food and their Effect on Health, ed. M. T. Huang, C. T. Ho and C. Y. Lee, American Chemical Society: Washington, D.C., 1992, pp. 135-149.

3 (a) J. L. Charlton, J. Nat. Prod., 1998, 61, 1447-1451; (b) S.-Y. Li, M.-D. Wu, C.-W. Wang, Y.-H. Kuo, R.-L. Huang and K.-H. Lee, Chem. Pharm. Bull, 2000, 48, 1992-1993.

4 H. L. Teles, J. P. H. Hemerly, P. M. Paoletti, J. R. C. Pandolfi, A. R. Araujo, S. R. Valentini, H. C. M. Jung, V. Da, S. Bolzani and H. S. Dulce, Nat. Prod. Res., 2005, 19, 319-323.

5 K. C. G. Jeng and R. C. W. Hou, Curr. Enzyme Inhib., 2005, 1, 11-20.

6 (a) P. C. Eklund, O. K. Långvik, J. P. Wärnå, T. O. Salmi, S. M. Willför and R. E. Sjoholm, Org. Biomol. Chem., 2005, 3, 3336-3347; (b) S. Yamauchi, Y. Hayashi, Y. Nakashima, T. Kirikihira, K. Yamada and T. Masuda, J. Nat. Prod., 2005, 68, 1459-1470.
7 For some examples of the effect of cytochrome P450-deppendent metabolic process on lignans, see: $(a)$ B. K. Sinha, H. M. Eliot and B. Kalayanaraman, FEBS Lett., 1988, 227, 240; (b) H. B. Niemeyer and M. Metzler, Anal. Technol. Life Sci., 2002, 777, 321-327.

8 K. K. Wolf, S. G. Wood, J. L. Allard, J. A. Hunt, N. Gorman, B. W. Walton-Strong, J. G. Szakacs, S. X. Duan, Q. Hao, M. H. Court, L. L. Von Moltke, D. J. Greenblatt, V. Kostrubsky, E. H. Jeffery, S. A. Wrighton, F. J. Gonzalez, P. R. Sinclair and J. F. Sinclair, Drug Metab. Dispos., 2007, 35, 1223-1231.

9 E. L. Cavalieri, K. M. Li, N. Balu, M. Saeed, P. Devanesan, S. Higginbotham, J. Zhao, M. L. Gross and F. G. Rogan, Carcinogenesis, 2002, 23, 1071-1077.

10 (a) P. Arivazhagan, K. Ramanathan and C. Panneerselvam, Experimental Gerontology, 2001, 37, 81-87; (b) O. Attanasi, P. Filippone, C. Fiorucci, R. Amorati, G. F. Peduli, L. Valgimigli and R. Saladino, J. Chem. Soc. Perkin Trans 2, 2001, 2142-2146.

11 H. J. Suh, M.-S. Chung, Y.-H. Cho, J.-W. Kim, D.-H. Kim, K.-W. Han and C.-J. Kim, Food Additives \& Contamin, 2005, 22, 1176-1188.

12 (a) For the effect of a tertiary hydroxyl group on the main lignin structure see S. Yamauchi, T. Ina, T. Kirikishira and T. Masuda, Biosci. Biotechnol. Biochem., 2004, 68, 183-192; (b) S. Yamauchi, Y. Hayashy, T. Kirikihira and T. Masuda, Biotechnol. Biochem., 2005, 69, 581582. For the effect of benzylic oxygen on antioxidant activity, see: S. Yamauchi, H. Hayashi, Y. Nakashima, T. Kirikihira, K. Yamada and T. Masuda, J. Nat. Prod., 2005, 68, 1459-1470. For the effect of benzylic oxygen on antimicrobial activity, see: K. Akiyama, M. Maruyama, S. Yamauchi, Y. Nakashima, T. Nakato, R. Tago, T. Sugahara, T. Kishida and Y. Koba, Biosci., Biotechnol., Biochem., 2007, 71, 17451751.

13 (a) C. Crestini, P. Pro, V. Neri and R. Saladino, Bioorg. Med. Chem, 2005, 13, 2569-2578; (b) C. Crestini, M. C. Caponi, D. S. Argyropoulous and R. Saladino, Bioorg. Med. Chem, 2006, 14, 52925302; (c) R. Saladino, C. Fiani, C. Crestini, G. D. S. Argyropoulous, S. Marini and M. Coletta, J. Nat. Prod., 2007, 70, 39-42.

14 R. Saladino, C. Fiani, M. C. Belfiore, G. Gualandi, S. Penna and P. Mosesso, Bioorg. Med. Chem., 2005, 13, 5949-5960.

15 P. Jancova, E. Anzenbacherova, B. Papouskova, K. Lemr, P. Luzna, A. Veinlichova, P. Anzenbacher and S. Vilim, Drug Met. Disp., 2007, 35, 2035-2039.

16 (a) S. Yamauchi, T. Sugahara, Y. Nakashima, K. Abe, Y. Hayashi, K. Akiyama, T. Kishida and M. Maruyama, Biosci. Biotechnol. Biochem., 2006, 70, 2942-2947; (b) S. Yamauchi, T. Sugahara, Y. Nakashima, A. Okada, K. Akiyama, T. Kishida, M. Maruyama and T. Masuda, Biosci. Biotechnol. Biochem., 2006, 70, 1934-1940.

17 C. Hartmann and V. Mayer, Chem. Ber., 1893, 26, 1727-1732.

18 M. Frigerio, M. Santagostino and S. Sputore, J. Org. Chem., 1999, 64, 4537-4538.

19 S. Quideau, L. Pouysegu, D. Deffieux, A. Ozanne, J. Gagnepain, I. Fabre and M. Oxoby, Arkivoc, 2003, VI, 106-119a nd references therein.

20 A. Ozanne, L. Pouységu, D. Depernet, B. Francois and S. Quideau, Org. Lett., 2003, 5, 2903-2906.

21 R. Bernini, E. Mincione, M. Barontini and F. Crisante, J. Agric. Food Chem., 2008, 56, 8897-8904.

22 (a) R. Bernini, E. Mincione, M. Barontini, and F. Crisante, It. Pat., MI2007A001110, 2007; (b) R. Bernini, E. Mincione, M. Barontini and F. Crisante, PCT 2008/110908, 2008.

23 P. C. Eklund, A. I. Riska and R. E. Sjöholm, J. Org. Chem., 2002, 67, $7544-7546$

24 S. C. Wilson, P. W. Howard, S. M. Forrow, J. A. Hartley, L. J. Lesley, T. C. Terence, L. R. Kelland, R. Lloyd and D. E. Thurston, J. Med. Chem., 1999, 42, 4028-4041.

25 S. Galland, N. Mora, M. A. Vian, N. Rakotomanomana and O. Dangles, J. Agric. Food Chem., 2007, 55, 7573-7579.

26 (a) See for example:N. J. Cartwright and A. R. W. Smith, Biochem. J., 1967, 102, 826-841; (b) V. Veturi, F. Zennaro, G. Degrassi, B. C. Okeke and C. V. Bruschi, Microbiol., 1988, 144, 965-973; (c) E. M. T. El-Mansi and S. C. K. Anderson, World J. Microbiol. Biotechnol., 2004, 20, 827-832; (d) M. Nishimura, I. Daisaku and J. Davies, Biosci., Biotechnol., Biochem., 2006, 70, 2316-2319.

27 B. Holmbom, C. Eckerman, P. Eklund, J. Hemming, L. Nisula, M. Reunanen, R. Sjöholm, A. Sunderg and S. Willför, Phytochem. Rev, 2003, 2, 331-340.

28 For example for oligomers lignans see: F. Kawamura, M. Miyachi, S. Kawai and H. Ohashi, J. Wood Sci., 1998, 44, 47-55. 
29 See for example: R. S. Ward, Nat. Prod. Rep., 1993, 10, 1-28.

30 (a) P. Rossner, P. Boffetta, M. Ceppi, S. Bonassi, Z. Smerhovsky, K. Landa, D. Juzova and R. J. Sram, Environ Health Perspect., 2005, 113, 517-520; (b) S. Bonassi, H. Norppa, M. Ceppi, U. Stromberg, R. Vermeulen, A. Znaor, A. Cebulska-Wasilewska, E. Fabianova, A. Fucic, S. Gundy, I.-L. Hansteen, L. E. Knudsen, J. Lazutka, P. Rossner, R. Sram and P. Boffetta, Carcinogenesis, 2008, 29, 11781183.
31 (a) C. Crestini and M. D'Auria, Tetrahedron, 1997, 53, 7877-7888; (b) H. Xu, S. Omori and Y.-Z. Lai, Holzforschung, 1995, 49, 323-325.

32 W. H. Hearon, H. B. Lackey and W. W. Moyer, J. Am. Chem. Soc., 1951, 73, 4005-1007.

33 P. Perry and S. Wolff, Nature, 1974, 156-158.

34 E. Rojas, R. Montero, L. A. Herrera, M. Sordo, M. E. Gonsebatt, R. Rodrigues and P. Ostrosky-Wegman, Mutat. Res., 1992, 282, 283-286.

35 J. R. K. Savage, Med. Genet., 1975, 12, 103-122. 